\title{
Ikeda Daisaku Compared to Cho Yonggi: Insights into Post-War Japanese and Korean History
}

\section{Brian Gold}

Ikeda Daisaku, as the third leader of Japan's largest so-called 'New Religion,' has received much journalistic and scholarly attention since his taking over leadership in 1960 of Soka Gakkai. None of these treatments, however, has looked at Ikeda in a rigorously comparative fashion. This essay will make an explicit comparison of Ikeda's career with Cho Yonggi, the South Korean Pentecostal Christian minister who founded the world's largest church, the Yoido Full Gospel Church. The comparison will be made to highlight unique features of Ikeda, Soka Gakkai, and Komeito, Soka Gakkai's affiliated political party which presently forms part of the ruling coalition of the Japanese government. It will be argued, however, that this comparison tells us more about modern (and post-war) Japan than about Ikeda, especially the continuing marginal social standing of 'New Religions' and the cost of being a charismatic leader in a society dominated by 'groupism'.

Ikeda Daisaku, as the third leader of Japan's largest so-called 'New Religion", has received much journalistic and scholarly attention since taking over leadership in 1960 of Soka Gakkai, a Buddhist lay organization started in the 1930 s and historically derived from the teachings of the $13^{\text {th }}$ century monk Nichiren. Cho Yonggi, the South Korean (henceforth 'Korean') Pentecostal Christian minister who in 1958 founded what became the world's largest church, the Yoido Full Gospel Church (YFGC), has also lately been the subject of academic analyses. ${ }^{2}$ None of these accounts, however, have looked at lkeda or Cho in a rigorously comparative fashion. This paper will make an explicit comparison between Ikeda's career and that of Cho's. The comparison highlights unique features of Ikeda, Soka Gakkai, Komeito, (Soka Gakkai's affiliated political party, which presently forms part of the ruling coalition of the Japanese government), and Cho. It will be argued that the unique features that arise from

\footnotetext{
1 'New Religions' refers to various newer syncretic religious sects that have arisen in Japan since the $19^{111}$ century and are commonly referred to as such in Japanese. Most of these sects blend elements of Shintoism and Buddhism. For simplicity's sake, no distinction is made between 'New Religions' and the so-called post-war sects called 'New New Religions'. Unlike many new religions in Japan, Soka Gakkai formally rejects the label of 'New Religion', regarding itself as the authentic form of Nichiren's ( $13^{\text {th }}$ century) Buddhism. ${ }^{2}$ See for example Wonsuk Ma, et al, eds., Dovid Yonggi Cho: a Close Look at His Theology and Ministry (Baguio City: APTS Press, 2004) and Harvey Cox, Fire from Heaven: The Rise of Pentecostal Spirituality and the Reshaping of Religion in the Twenty-First Century (Reading, MA: Addison Wesley, 1995), Chapter 11.
} 
such a comparison tell us more about post-war Japan and Korea than about Ikeda or Cho.

First, the many similarities in background, career, and the development of their respective organizations will be noted. Next, the relatively few differences between Ikeda and Cho will pose a paradox: why have Ikeda and the Soka Gakkai been held in much lower esteem within post-war Japanese society than Cho was in contemporaneous Korean society when their characters and accomplishments would indicate a rough equivalence? The answers to this paradox will provide insight into post-war Japanese and Korean trends regarding the perceived role of religion in society and more general attitudes in both countries towards assertive, individualistic leadership.

As French historian Paul Veyne wrote, "every history is in some way a comparative history." 3 While the physical sciences employ objective external standards for measuring the phenomenon they study, any judgement of a historical event can only be understood by a comparison with another historical event, either made implicitly by the reader, or made explicit by the historian. A comparative approach, which will provide some sort of 'objective' external measure, is especially necessary when studying religious movements categorized as 'New Religions' such as Soka Gakkai. It bas been a struggle within the last few decades in scholarship on religion to shed preconceived notions of what constitutes a longstanding 'religion' versus a newer 'cult' and to drop the pejorative implications inherent in the latter term. ${ }^{4}$ The journalistic and partisan literature on Ikeda Daisaku's life and on Soka Gakkai is voluminous and sensationalist. Even the scholarly literature on Soka Gakkai has to be approached with caution to avoid its 'sect-bashing' tendencies. ${ }^{5}$ In contrast, the scholarly literature and media attention on Cho has been, with a few exceptions, much less pejorative. ${ }^{6}$ The many similarities that are revealed through a comparison between the two figures helps to avoid an overly panegyric analysis regarding Ikeda, despite the relative bias of the literature.

From their common Sinocentric cultural heritage, to language, and to a more recent and troubled history, there are no countries in the world more similar than Japan and Korea. This similarity allows one to anticipate many of the numerous congruities in the careers of lkeda and Cho and in the development of

\footnotetext{
${ }^{3}$ Paul Veyne, Writing History: Essay on Epistemology (Middletown, CN: Wesleyan Univ., 1984), 46.

${ }^{4}$ Massimo Introvigne, "The Future of Religion and the Future of New Religion," $<$ http:/www.cesnur.org/2001/mi june03.htm>, Center for Studies on New Religion.

${ }^{5}$ See James R. Lewis, "Sect-Bashing in the Guise of Scholarship: A Critical Appraisal of Select Studies of Soka Gakkai," Marburg Joumal of Religion Vol. 5, No. 1 (July 2000).

"The most cited and vociferous attack on Cho for 'heresy' against Christianity is found within Dave Hunt and T. McMahon, The Seduction of Christianity: Spiritual Discermment in the Last Days (Eugene: Harvest House, 1985).
} 
Soka Gakkai and the Yoido Full Gospel Church which will be summarily outlined below. It also focuses attention on the few critical differences between the two.

Both Ikeda and Cho were born within the Japanese empire in the prePacific War Showa era, and subsequently both experienced wartime devastation and American occupation of their countries. (Of course Cho first experienced a Japanese occupation until 1945 that was much longer than the subsequent American one.) Both were the offspring of small merchants. Both found their vocation in young adulthood after near-deadly yet spiritually fruitful encounters with tuberculosis, with Ikeda finding his mentor Toda Josei, later the second leader of Soka Gakkai ${ }^{7}$, at the age of 19, and Cho becoming a minister at the age of $22 .{ }^{8}$ From this early start, each enjoyed perhaps the most influential post-war career of any religious figure in their respective countries.

Their own achievements and those of their respective organizations were to some degree the result of developments in the religious environment of their individual countries. The most dynamic development in Japanese religion in the post-war era was the rise of the 'New Religions' of which Ikeda's Soka Gakkai with 8 million members remains the largest. As of 1994 the 'New Religions' claimed membership totaling approximately $10 \%$ of the Japanese population. ${ }^{9}$ Since the end of the Pacific War, Korean Christianity has increased from $2 \%$ to approximately $25 \%$ of the population. ${ }^{10}$ Cho's Yoido Full Gospel Church is the largest single church in the world, with 700,000 members. " Both Japanese "New Religions' and Korean Christianity have been the first to successfully introduce on

\footnotetext{
'Toda was leader of Soka Gakkai from 1945 to his death in 1958.

${ }^{8}$ About Daisaku Ikeda: <http://www.sgi-usa.org/thesgiusa/aboutsgi/ikeda.html > SGI-USA; Tadakuni Nakaba, Daisaku Ikeda (n.l.n.p., n.d.), cited in Hirotatsu Fujiwara, I Denounce Soka Gakkai, translated by Worth C. Grant (Tokyo: Nisshin Hodo, 1970), 139-140; Younghoon Lee, "The Life and Ministry of David Yonggi Cho and the Yoido Full Gospel Church," in David Yonggi Cho: A Close Look at His Theology \& Ministry, eds. Wonsuk Ma, et al (Baguio, Philippines: APTS, 2004), 5.

'Figures for both Soka Gakkai and the overall size of 'New Religions' can be found in Ian Reader, Religion in Contemporary Japan (Honolulu: Univ. of Hawaii, 1991), 194;

Population in Statistics Handbook of Japan, 2004:

$<$ http://ww.stat.go.jp/english/data/handbook/pdf/c02cont.pdf $>$ Statistics Bureau, Ministry of Internal Affairs and Communication, Chapter 2; Daniel A. Metraux, "Religious Terrorism in Japan: The Fatal Appeal of Aum Shinrikyo," Asian Survey Vol. 35, No. 12 (Dec., 1995), 1143.

${ }^{10}$ Donald N. Clark, Christianity in Modern Korea (Lanham, MD: University Press of America, 1986), 1.

"Lee. 3.
} 
a widespread basis the idea of exclusive adherence to a religion within their respective cultures. ${ }^{12}$

Both Soka Gakkai and the YFGC experienced their highest rates of membership growth during the decades when each country underwent their highest rates of economic growth. From the Korean War boom to the 'Nixon shocks' of the early '70s Soka Gakkai membership increased from 5,000 to the approximately 8 million it still has today. ${ }^{13}$ Korea's highest economic growth rates occurred from the early ' 60 s up to the 1997 Asian Crisis; during the same period YFGC's membership totals increased from 3,000 to the 700,000 it has today. ${ }^{14}$

This link between economic and membership growth rates is not completely coincidental. It has been argued that in both Japan and Korea religions have a long-standing traditional bent towards the supernatural provision of material benefits. ${ }^{15}$ Within this cultural background many Japanese and Koreans in the post-war era may have been more than usually preoccupied with material benefits as rapid economic growth meant for them a dizzying rise from immediate post-war poverty to vastly increased personal economic opportunities. Both Soka Gakkai (initially under Toda, and then Ikeda) and YFGC (entirely under Cho) were well positioned in terms of their theology to meet the spiritual needs of such people.

Scholars have noted a distinctive emphasis on earthly benefits and secular concerns within the Soka Gakkai tradition of Buddhism that can be traced through the $13^{\text {th }}$ century monk Nichiren up to Toda who laid the key present-day philosophical foundations for Soka Gakkai in the 1940s. ${ }^{16}$ A similar emphasis on faith and vocal prayer leading to material riches has been in the forefront of Cho's theology, which is clearly derived from the 'prosperity gospel' that arose within

\footnotetext{
${ }^{12}$ Reader, Religion, 8; Donald Baker, "Modernization and Monothcism: How Urbanization and Westernization Have Transformed the Religious Landscape of Korea," Unpublished Paper, 2003.

${ }^{13}$ Daniel Metraux, The Hislory and Theology of Soka Gakkai: A Japanese New Religion (Lewiston, NY: Edwin Mellen, 1988), 35; James W. White, The Sokagakkai and Mass Society (Stanford: Stanford Univ., 1970) 303; Reader, Religion, 194.

14 Lee, 7 \& 9.

${ }^{15}$ See for example Ian Reader \& George J. Tanabe, Jr., Practically Religious: Worldly Benefits and the Common Religion of Japan (Honolulu: Univ. of Hawaii, 1998) and Don Baker, "Monks, Medicine and Miracles: Health, Disease, and Religion in Early Korean History," Unpublished Paper.

${ }^{16}$ Noriyoshi Tamaru, "Soka Gakkai in Historical Perspective", in Global Citizens: The Soka Gakkai Buddhist Movement in the World, eds. David Machacek \& Bryan Wilson (Oxford: Oxford Univ, 2000), 24; Metraux, The History and Theology of Soka Gakkai, 35-36; Bryan Wilson \& Karel Dobbelaere, A Time 10 Chant: The Soka Gakkai Buddhists in Britain (Oxford: Clarendon, 1994), 1 I.
} 
American Pentecostal circles in the 1940s. ${ }^{17}$ Armed with such a theological orientation, both Soka Gakkai and the YFGC attracted many of the economically precarious (urban workers and petit bourgeoisie) to their folds during their decades of greatest growth. ${ }^{18}$ The small business family background of both Ikeda and Cho no doubt aided them in appealing to these economic classes.

In the relative chaos of the post-war period the strongly sectarian nature of both Soka Gakkai and Cho's YFGC, a feature that has deep roots in both Nichiren Buddhism and Pentecostalism, is often credited as being an important factor in attracting new members into each organization. Also attractive, and related to their sectarian nature, was that both organizations offered members a relatively ordered community and clear tasks for helping the organization grow. ${ }^{19}$ By 1952 Soka Gakkai developed an internal organization unique amongst contemporary Japanese 'New Religions'. It featured a highly centralized pyramid structure but at the same time encouraged differing arms of Soka Gakkai to compete vigorously for new recruits. ${ }^{20}$ In 1964 Cho instinted a system of organizing YFGC members into laity-led home cell groups that were centres for proselytization outside of centralized weekly worship. ${ }^{21}$ While the organizational structure of Soka Gakkai and the YFGC differed, the result was the same: fast-growing organizations that held together rather than fragmenting as they got larger.

Both Ikeda and Cho have been successful in taking their missions overseas. Ikeda initiated the overseas expansion of Soka Gakkai and presently there are approximately 60,000 Soka Gakkai followers in Europe and North America. ${ }^{22}$ Cho has not aimed to create overseas branches of the YFGC, but his

\footnotetext{
${ }^{17}$ For origins of the 'prosperity gospel' (also called the 'Faith movement') see J.N. Hom, From Rags to Riches: An Analysis of the Faith Movement and Its Relation to the Classical Pentecostal Movement (Pretoria, South Africa: Univ. of South Africa, 1989); Vinson Synan, The Holiness-Pentecostal Tradition: Charismatic Movements in the Twentieth Century (Grand Rapids, MI: Eerdmans, 1997), 222-224; On the link between the American 'prosperity gospel' and Cho Yonggi see Myung Soo Park, "David Yonggi Cho and International Pentecostal/Charismatic Movements," Joumal of Pentecosial Theology 12.1 (2003), 107-128; H.S. Kim. "'Yesu mitko pokpatuseyo": han'guk chonjaeng ihuui kitokkyo sinang yangt'ae" ["'Believe in Jesus and Receive a Blessing': Christian Faith Forms Since the Korean War"], Han'guk kitokkj'o yoksa yon 'guso sosik, [The Institute for Korean Church History Bulletin] \#37, July 3, 1999

${ }^{18}$ Hiroshi Aruga, "Soka Gakkai and Japanese Politics," in Global Citizens, 103; Hong Young-gi, "The Charisma of Cho Yonggi and its Routinization in the Yoido Full Gospel Church of Korea," Journal of Asian Missions 2/1 (2000), 70; Lee, 5-6.

${ }^{19}$ Mikiso Hane, Premodern Japan: A Historical Survey (Boulder, CO: Westview Press, 1991), 77-78; Anga, 105-106; Synan, The Holiness-Pentecostal Tradition, 187; Lee, 5-6. ${ }^{20}$ Aruga, 104-105.

${ }^{21}$ David S. Lim, "A Missiological Evaluation of David Yonggi Cho's Church Growth," in David Yonggi Cho, 182 \& 191.

${ }^{22}$ Lome L. Dawson, "The Cultural Significance of New Religious Movements: The Case of Soka Gakkai," Sociology of Religion Vol. 62, Iss. 3 (Fall 2001), 337-364.
} 
fluency in several languages including English and constant travel across the world proselytizing and providing support for new churches has earned him an international reputation among charismatic, Pentecostal, and 'prosperity gospel' oriented Christians. ${ }^{23}$

Despite representing two different religious traditions, Ikeda and Cho have each worked within a similar social environment and spiritual orientation to achieve roughly equivalent prominence within the religious sphere of each of their countries. These similarities reinforce the overall parallels in Japanese and Korean history and culture. In the case of Cho, the spiritual similarities are not entirely accidental: he has identified the Holy Spirit's power to bless a believer's life to be God's altemative to the power of the 'evil spirit world' that religions such as Soka Gakkai are, in his opinion, unknowingly calling upon. ${ }^{24}$ Somewhat typically in the modem history of Japan and Korea, this is yet another example of a Korean consciously taking the measure of his cultural practices in comparison to Japan, an endeavor not often reciprocated. Be that as it may, as Ikeda and Cho have each achieved equal success following similar tactics, it could be expected that both have enjoyed a fairly similar social standing and regard within each country. In fact, while Cho's career has not been free of controversy, his overall standing in Korean society could not be more different from the seemingly endless vilification Ikeda and Soka Gakkai have received from much of Japanese society over the last several decades. This startling difference in overall public reputation between Cho and Ikeda will be described and the reasons for Ikeda's more controversial status found both within Soka Gakkai's active participation in formal politics since the 1950s and within larger trends in modern Japanese and Korean history.

Cho Yonggi has enjoyed a relatively untroubled career. Koreans of all religious backgrounds have been well aware of and have respected his worldwide fame for having the 'largest church in the world'. Despite this, however, Cho has been seen as somewhat too sectarian to be the 'leading representative' of Korean Protestants in the way that Billy Graham is commonly seen as America's leading Protestant. ${ }^{25}$ There has been some serious theological and denominational

\footnotetext{
${ }^{23}$ Vinson Synan, "The Yoido Full Gospel Church". Cyberjournal for PentecosialCharismatic Research, <http://www.pctii.org/cybertabl.html> 2 (1997); Paul Gifford, African Christianity: Its Public Role (Bloomington, IN: Indiana Univ., 1998), 78.

${ }^{24}$ Allan Anderson, "The Contextual Pentecostal Theology of David Yonggi Cho," in David Yonggi Cho, 146.

${ }^{25} \mathrm{Han}$ Yong Chik ihu chitochanun nuku, Kyokyekicba 55 myong solmun chosa, Kim Chun Kon moksa 1 wiro kophyo [After Han Kyong-Chik, who? Minister Kim Chun-Kon Selected as Number One Amongst Survey of 55 Christian Journalists]

$<$ http://www.cjak.or.kr/news/news-73.htm>, Christian Joumalists Association of Korea, Nov. 10, 2004; "Wolgan [sinanggye], '20 Seki han'guk kyohoe 20 tae inmul' sonjong" ["Faith monthly selects top 20 leaders of the $20^{\text {" }}$ century church"], Sekye Ilbo [World Daily]. Nov. 25, 1999, 19; Mark A. Noll, A History of Christianity in the United States and Canada (Grand Rapids, MI: Eerdmans, 1992), 509.
} 
controversy regarding Cho within the Korean Christian community. This came to a head in the early ' $80 \mathrm{~s}$ when more mainstream elements of Korean Christianity, particularly Presbyterian ones, identified heretical tendencies within Cho's prosperity teaching that they considered an updated form of Korean 'shamanism'. As Cho developed his own and his church's ability to defend itself theologically, however, the vast majority of the Korean Christian community accepted Cho again as a fellow Christian. ${ }^{26}$

In comparison to this relatively placid picture, Ikeda has been the target of withering accusations throughout his career. Even before becoming leader, Ikeda was arrested and then released for lack of proof in 1957 for suspected vote buying for Soka Gakkai candidates in an election. ${ }^{27}$ In 1969 a political scholar named Hirotatsu Fujiwara published a book-long attack on Soka Gakkai called I Denounce Soka Gakkai in which Ikeda was accused of being fascist, the 'Emperor' of his organization, and the center of a personality cult. ${ }^{28}$ The lasting reputational damage to Ikeda from this book may have been as much from Soka Gakkai's extremely clumsy attempts to prevent its publication as from the work itself, ${ }^{29}$ which is largely as incoherent and illogical as it claims Soka Gakkai to be. ${ }^{30}$ In 1990-91 the Nichiren Shoshu order of monks severed connections with Soka Gakkai, which has always officially been a lay organization. During this acrimonious and highly publicized split one of the accusations made by Nichiren Shoshu was that Ikeda was a "virtual dictator" and the center of a personality cult. ${ }^{31}$ Finally, in 1995, and to widespread publicity, a fired Soka Gakkai employee accused Ikeda of raping her repeatedly over the course of decades. Ikeda's eventual complete exoneration of the charges by the Japanese Supreme Court received very little follow-up media attention. ${ }^{32}$

The contrasting public images of Ikeda and Cho seem especially difficult to reconcile with a comparison of their actual positions within the historical

\footnotetext{
${ }^{26} \mathrm{Kim},{ }^{\text {"' }}$ Yesu mitko pokpatuseyo $\cdots$; Wonsuk Ma, "Toward the Future of David Yonggi Cho's Theological Tradition," in David Yonggi Cho, 260-261.

${ }^{27}$ White, 162-163.

${ }^{28}$ Hirotatsu Fujiwara, 1 Denounce Soka Gakkai, translated by Worth C. Grant (Tokyo: Nisshin Hodo, 1970), 33-58 [entitled "Chapter Five: The Emperor of Soka Gakkai, Daisaku Ikeda and the Staff"'].

${ }^{29}$ Takesato Watanabe, "The Movement and the Japanese Media," in Global Citizens, 229.

${ }^{30}$ The incoherence of I Denounce Soka Gakkai may lay in the translation of the English version I have access to - the "Translator's Preface" (pp. 9-1I) alludes to the lack of time and difficulty of the task.

${ }^{31}$ Daniel A. Metraux, "The Dispute Between the Soka Gakkai and the Nichiren Shoshu Priesthood: A Lay Revolution Against a Conservative Clergy", Japanese Journal of Religious Studies 19/4 (1992), 329.

32 Adam Gamble \& Takesato Watanabe, A Public Betrayed: An Inside Look at Japanese Media Atrocities and Their Warnings to the West (Washington, D.C.: Regnery, 2004), Chapter 6.
} 
development of Soka Gakkai and the YFGC. In this regard they are only similar in that both are the subjects of considerable veneration within their respective organizations. Cho is viewed within the YFGC as God's chosen servant who is closer to the Divine than most while some within Soka Gakkai have speculated that Ikeda is the reincarnation of Nichiren. ${ }^{33}$

If either of these two were the 'virtual dictator' of their organization it would be Cho Yonggi. Cho founded the YFGC and it rose to its leading position virtually on his charisma, skills, and entrepreneurial daring alone. ${ }^{34}$ All of its seminal innovations - its contributions to global 'prosperity gospel' theology, its development of neighborhood cell groups, usually led by women, its pioneering of the infrastructure and organization needed for 'mega-churches' - were all Cho's own ideas. ${ }^{35}$ Cho's importance is such that the continued viability of the Church after his death is a key concern. ${ }^{36}$

As the third leader of an organization that started when he was still a child Ikeda has not been nearly as critical to the development of Soka Gakkai. While he has enjoyed relatively undisputed leadership since his ascension to the position in 1960, Ikeda can claim full authorship of few of the most distinctive features of Soka Gakkai. As mentioned above, Toda formulated most of its key modern doctrine. In the 1950s Toda also oversaw both the start of its real growth spurt in size and its entry into Japanese politics. ${ }^{37}$ If anything, Ikeda has been a moderating influence on the practice and image of Soka Gakkai. One of the most enduring negative legacies in terms of image for the Soka Gakkai was its widespread use in the 1950s and early 1960s of extremely aggressive recruitment techniques (called shakubuku) that sometimes bordered on intimidation and violence. Ikeda's ascension was critical to the practical abandonment of this practice over the course of the 1960 s. $^{38}$

Cho's preferred public image has always been that of the Pentecostal minister preaching throughout the world, planting new churches, and meeting only other prominent Protestant ministers. Like Cho, Ikeda is a world-traveler. In fact, the one major new direction for Soka Gakkai that can clearly be credited to Ikeda is the start of overseas organizations. ${ }^{39}$ In image, however, Ikeda's has been that of

\footnotetext{
${ }^{33}$ Hong, 77; Jane Hurst, "A Buddhist Reformation in the Twentieth Century: Causes and Implications of the Conflict between the Soka Gakkai and the Nichiren Shoshu Priesthood," in Global Citizens, 76.

${ }^{34}$ See Hong.

${ }^{35}$ It must be noted that Cho himself has attributed all of these innovations to commands given to him directly by God.

${ }^{36}$ Hong, 88.

${ }^{37}$ White, 41 \& $43-44$

${ }^{38}$ White, 49-50; Karel Dobbelaere, Soka Gakkai: From Lay Movement to Religion (U.S.A.: Signature Books, 1998), 5-6.

${ }^{39}$ Dobbelaere, 7.
} 
a non-sectarian world statesman for peace, travelling the globe establishing cultural institutions and meeting Nobel laureates, the U.N. Secretary-General, and icons of democracy such as Nelson Mandela. ${ }^{40}$ Ikeda's close relationship to top Chinese Communist leaders and a number of Komeito missions to China in 1971 and the summer of 1972 likely played a role, albeit minor, in the re-establishment of diplomatic ties between China and Japan in September 1972. ${ }^{41}$

Considering that in comparison with Ikeda Cho would seem to have been at least as sectarian and domineering, if not more, in both his actual career and projected image, it remains to be explained why Ikeda's standing in Japan compares so badly with Cho's in Korea. The reasons for this are found in a number of clear differences between Japanese and Korean history. One set of reasons relates to the history of 'New Religions' in Japan versus the history of Christianity in Korea. The other relates to very different perceptions of the role of religion in politics within Japan and Korea. Finally, more nebulous issues of the role of individualism and leadership in post-war Japan versus their role in Korea are brought to bear on the question.

The post-war Japanese public has generally disliked 'New Religions' such as Soka Gakkai for several reasons. First, they carry a stigma in not being part of the millennia-old established (kisei) religions of clerical Shinto and Buddhism that are firnly tied in with the mainstream. (Most Japanese do not view Soka Gakkai as being Buddhist, despite its own representation to the contrary. ${ }^{42}$ Accordingly, the post-war Japanese media tended to treat traditional religions and mainstream Christian denominations deferentially, and 'New Religions' in a sensationalist inanner. ${ }^{43}$ Finally, the perceived focus of 'New Religions' on worldly material benefits made them the subject of much derision in Japanese intellectual circles. ${ }^{44}$

In Korea, in contrast, Christianity and in particular Protestantism since its introduction to the country in the late $19^{\text {th }}$ century has often been, in fact as well as perception, a leading standard-bearer of Korean modernization in setting up the institutions necessary for a thriving civil society. Christian groups set up most of Korea's first and most prestigious modern universities and hospitals. ${ }^{45}$ Crucially, too, Christianity in Korea has long been linked to Korean nationalism because of

${ }^{40}$ Crusades Abroad, <http://www.fgtv.org/n_Korea/ch_photo/abroad.asp>, Full Gospel TV, David Yonggi Cho; Nell L. Kennedy, Dream Your Way to Success: The Story of Dr. Yonggi Cho and Korea Plainfield, NJ: Logos International, 1980, see photos before page 124:

White, 50; Daisaku Ikeda, A New Humanism: The University Addresses of Daisaku Ikeda

(N.Y.: Weatherhill, 2002), sce photos between pages 80 and 81 .

${ }^{41}$ Metraux, The History and Theology of Soka Gakkai, 153-165.

${ }^{42}$ Reader, Religion, 197-198

${ }^{43}$ Watanabe, 209-210.

${ }^{44}$ Reader \& Tanabe, Practically Religious, 3.

${ }^{45}$ Andrew Eungi Kim, "Christianity, Shamanism, and Modernization in South Korea," Cross Currents (Spring-Summer 2000), 112-118. 
the leading role of Christians in the anti-colonial (i.e. anti-Japanese) movement before WWII.

As mentioned earlier, both the 'New Religions' in Japan and Christianity in Korea have been the first religions in either country to achieve widespread success while at the same time requiring exclusive spiritual devotion from their adherents. The effect of this call for exclusivity on the majority who did not join these religions could not, however, have been more different. In Korea the idea of identifying oneself as a member of one religion exclusively - introduced by Christianity - has spread in the post-war period to Korean Buddhism and Korea's own 'New Religions'. The role of Christianity as an icon of modemity made its sectarianism a model to adopt, not disparage. ${ }^{46}$ In contrast, the exclusivity that 'New Religions' in Japan demanded, and the overly aggressive prostelytization that went along with it, cut directly against post-war Japanese syncretism where rituals of various religions act as markers of life-stages, for example, Shintoism for birth, Christianity for marriage, and Buddhism for death. ${ }^{47}$

From a closely intertwined early $20^{\text {th }}$ century history, the Japanese and the Koreans have drawn opposite conclusions regarding the appropriate role of religion in politics, conclusions that in the Japanese case have had alınost invariably negative consequences for Ikeda. Since the late $19^{\text {th }}$ century not only has Korean Christianity been a leader in creating a modern civil society, it had a major role in fostering Korean nationalism and resisting Japanese imperialism. ${ }^{48}$ In the Korean War era and afterwards voraciously anti-Communist and politically conservative Christians such as Cho had an influence in maintaining a hard line towards North Korea while more politically liberal Christians have been a catalyst for the democracy movement. The conclusion for Koreans, whether Christian or not, has been that it is acceptable and even laudatory for Christians to use their faith as an overt guide to their political activism, whether on the right or left.

In contrast, Japan in the $20^{\text {th }}$ century has had a troubled and complex history in the mixture of religion with politics. Ikeda's indirect association with Komeito has made him susceptible to being attacked as both an extreme rightist and a threat to the LDP-allied establishment that ruled Japan for most of the postwar period. The very same State Shintoism that provided a target for Korean Christian nationalist defiance during the Japanese occupation of Korea has provided Japanese in the post-war period with an object lesson in the dangers of mixing religions with politics. A generalized suspicion of Ikeda's ultimate intentions for Komeito has lasted throughout the post-war period. ${ }^{49}$

\footnotetext{
${ }^{46}$ Baker, "Modemization and Monotheism"

${ }^{47}$ Reader, Religion, 199.

${ }^{48}$ See Kenneth M. Wells, New God, New Nation: Prolestants and Self-Reconsiruclion

Nationalism in Korea, 1896-1937 (Honolulu: Univ. of Hawaii, 1990).

${ }^{49}$ Fujiwara, 83; H. Neill McFarland, The Rush Hour of the Gods: A Study of the New"

Religious Movements in Japan (N.Y.: Harper \& Row, 1967), 216-217; Howard W. Frencl1,
} 
This suspicion has taken on greater specificity when the ultra-nationalist Nichiren roots of Soka Gakkai have been considered. During WWII the large majority of Japanese Buddhist organizations were supporters of the war and some of the thirty subschools of Nichiren Buddhism produced the most virulent of rightist nationalists. Regarding Komeito as a potential far right organization because of these Nichiren roots seems less plausible however when it is realized that the same Nichiren Buddhism also produced prominent anti-nationalist pacifist endeavours in the pre-war era such as the Shinko Bukkyou Seinen Domei of Giro Seno. Soka Gakkai leaders themselves were imprisoned during the war and were only freed if they renounced Nichiren Shoshu beliefs; Soka Gakkai's first leader, Tsunesaburo Makiguchi, died under captivity. ${ }^{50}$ Regarding this, Shunsuke Tsurumi believes that in fact Makiguchi's death stands as a symbol of opposition to State Shintoism and that "the spectacular...growth of the Soka Gakkai... may be attributed to the death of its leader...in prison during the war." 51

It can be argued that Ikeda's and Komeito's long-standing advocacy of peace and its anti-establishment posture accurately reflects Soka Gakkai's historical roots. But being overtly opposed to the longest-running political establishment of the post-war era, namely the LDP, has made Ikeda the constant source of attacks from the goveming party. In fact, the widespread publicity mentioned above regarding the 1995 rape accusations made against lkeda and other 'smear campaigns' have been identified as being generated by tabloid media with close connections to the LDP. ${ }^{52}$ Since the 1999 governing alliance between the LDP and the New Komeito, the attacks on lkeda have stopped and over the longer term an improvement in Ikeda's image may be expected. ${ }^{53}$

A final difference between post-war Japan and Korea that may help to explain the differing public status of Ikeda and Cho can be found in broader social attitudes towards assertive leadership and entrepreneurialism. Both Ikeda and Cho are self-promoting, self-made leaders. On a global scale Japanese and Korean cultures could be ranked very similarly in terms of both being highly grouporiented (or dominated by 'groupism', to use the term used in the literature on Japan). However, when the two countries are compared to each other it is clear

\footnotetext{
"A Sect's Political Rise Creates Uneasiness in Japan," New York Times, Nov. 14, 1999 <http://www rickross.com/reference/gakkai/gakkail.html>.

${ }^{50}$ Shunsuke Tsunumi, An Intellectual History of Wartime Japan: 1931-1945 (London: KPI, 1982), 51; Tamaru, 26; Aruga, 99.

5) Shunsuke Tsurumi, A Cultural History of Postwar Japan: 1945-1980 (London: KPI, 1984), 131.

${ }^{52}$ Watanabe, 218-219: see also Gamble \& Watanabe.

${ }^{53}$ Daniel A. Metraux, "Japar's Search for Political Stability: The LDP-New Komeito Alliance," Asian Survey Vol. 39, No. 6 (Nov.-Dec., 1999), 926; "Lotus Politics," The Economist Nov. 27, 2004, 34.
} 
that Japan in the post-war period has been much more inhospitable to persons with the assertiveness of an Ikeda or a Cho.

A frequent explanation given for the post-war economic 'success' (and more recently in the 1990s, the 'failure') of the Japanese is their propensity towards consensus in all decisions. ${ }^{54}$ While not endorsing such a simplistic portrait of the Japanese, Gerald Curtis, a noted expert on Japanese politics, has noted that in the political sphere in the 1990s there seemed to be a lack of leadership and a complex system of economic, political, and social institutions that inhibited radical change. ${ }^{55}$ Other scholars, both foreign and Japanese, who have recently written on the topic agree that in the post-war era Japanese society has been dominated by consensus building cultural forms that suppress a long-history of Japanese individualism and charismatic leaders. ${ }^{56}$ One such writer, Yamazaki Masakazu, notes that in particular the belief system of Nichiren Buddhism promotes strong individualism. ${ }^{57}$

In contrast, modern Korean history is replete with strong, charismatic leaders, even to the point of full-blown personality cults (such as in North Korea) that far exceed anything that could ever be conceived for Ikeda. While a collective ethos in Korean culture is prevalent, an enduring history of 'self-assertion' on the part of Koreans has always been part of the cultural legacy. ${ }^{58}$ A propensity for entrepreneurship is an indicator of assertive leadership skills in any culture, and a recent global survey of entrepreneurship revealed that while Korea scored as one of the most entrepreneurial countries in the world, Japan was ranked very low. ${ }^{59}$

In conclusion, an explicitly comparative approach to evaluating Ikeda and Cho, using each as a 'mirror' for the other, has allowed for the distinctive features of the Japanese historical response to Ikeda and the Korean historical response to Cho to stand out more clearly. The summary of the many similarities and successes in the careers of Ikeda and Cho demonstrate that both followed very similar strategies, such as an appeal of inaterial well-being to economically

\footnotetext{
${ }^{54}$ See examples of this argument surveyed in Chalmers Johnson, MITI and the Japanese Miracle: The Growth of Industrial Policy, 1925-1975 (Stanford: Stanford Univ., 1982), 8.

ss Gerald L. Curtis, The Logic of Japanese Politics: Leaders, Institutions, and the Limits of Change (N.Y.: Columbia Univ., 1999), 5 \& 241.

${ }^{56}$ Ian Neary, "Leaders and Leadership in Japan," in Leaders and Leadership in Japan (Surrey: Japan Library, 1996), 11-13; Kuniko Miyanaga, The Creative Edge: Emerging Individualism in Japan (New Brunswick, U.S.A.: Transaction, 1991), 1; Yamazaki Masakazu, Individualism and the Japanese: An Alternative Approach to Cultural Comparison, translated by Barbara Sugihara (Tokyo: Japan Echo, 1994), 93-104.

37 Yamazaki, 57.

${ }^{58}$ Carter J. Eckert, et al, Korea, Old and New: A History (Seoul: Ilchokak, 1990), 409.

59 See Andre van Stel, et al, "The effect of entrepreneurship on national economic growth: An analysis using the GEM database," Paper prepared for The First GEM Research Conference: "Entrepreneurship, Government Policies, and Economic Growth," Berlin, 1-3 April, 2004.
} 
precarious classes coping with post-war chaos, and with similar successes. Answering the question of why, if so similar, Ikeda has been so much more a controversial figure in his society than Cho, when in fact Ikeda has probably been a more moderating influence, reveals more about Ikeda's place and time than it does about Ikeda. What has been revealed is the depth of modern Japanese resistance to religions demanding exclusivity, and the legacy of the disaster of WWII and state Shintoism in terms of suspicion towards an overtly religiouspolitical entity such as Komeito. In contrast, Cho's career demonstrates post-war Korea's acceptance of Christianity as a positive paradigm of modernity, political activism, and religious sectarianism, and its comfort with more individualist leadership styles. 